\title{
Blastococcus jejuensis sp. nov., an actinomycete from beach sediment, and emended description of the genus Blastococcus Ahrens and Moll 1970
}

\author{
Soon Dong Lee
}

Correspondence

Soon Dong Lee

sdlee@cheju.ac.kr
Department of Science Education, Cheju National University, Jeju 690-756, Republic of Korea
A novel actinomycete, strain KST3-10 $0^{\top}$, was isolated from sand sediment of a beach in Jeju, Korea, and was subjected to polyphasic taxonomic characterization. The organism produced circular, smooth, translucent, apricot-coloured colonies comprising coccoid- or rod-shaped cells. Phylogenetic analyses based on 16S rRNA gene sequences showed that the organism belonged to the family Geodermatophilaceae and consistently formed a distinct sub-branch outside the radiation of the genus Blastococcus. The organism showed $16 \mathrm{~S}$ rRNA gene sequence similarity values of $98.2 \%$ with respect to Blastococcus aggregatus DSM $4725^{\top}$ and $98 \cdot 1 \%$ with respect to Blastococcus saxobsidens $\mathrm{BC} 444^{\top}$. The type strains of the two Blastococcus species shared $98.2 \%$ sequence similarity with respect to each other, whereas the levels of sequence similarity between the novel organism and the type strains of the less closely related neighbours,

Modestobacter multiseptatus and Geodermatophilus obscurus, were in the range $96 \cdot 2-96 \cdot 9 \%$. The physiological, biochemical and chemotaxonomic data revealed that the novel organism can be readily differentiated from members of the genus Blastococcus and that it merits separate species status. On the basis of the phenotypic and genotypic evidence, strain KST3-10 ${ }^{\top}$ represents a novel species of the genus Blastococcus, for which the name Blastococcus jejuensis sp. nov. is proposed. The type strain is KST3-10 ${ }^{\top}\left(=\right.$ NRRL B- $\left.24440^{\top}=\mathrm{KCCM} 42251^{\top}\right)$.
The genus Blastococcus was first proposed by Ahrens \& Moll (1970) to accommodate aerobic, Gram-positive, coccusshaped bacteria, which often reproduce by budding and multiple fission. The only (and type) species of the genus Blastococcus, Blastococcus aggregatus (Ahrens \& Moll, 1970), was isolated from the Baltic Sea. Although the genus name was included on the Approved Lists of Bacterial Names (Skerman et al., 1980), it has not been described in detail taxonomically for many years. Its description was recently emended after a detailed taxonomic investigation that included morphological, chemotaxonomic and phylogenetic analyses; this resulted in the addition of the second species, Blastococcus saxobsidens (Urzi et al., 2004). The genus is characterized chemotaxonomically by the following features: the presence of meso-diaminopimelic acid in the cell wall; the presence of MK- $9\left(\mathrm{H}_{4}\right)$ as the major menaquinone; cellular fatty acids consisting mainly of unsaturated and iso-branched acids; a phospholipid profile that includes diphosphatidylglycerol, phosphatidylglycerol, phosphatidylinositol and phosphatidylethanolamine; and a DNA G + C content of $74 \mathrm{~mol} \%$. Phylogenetically, members of this

The GenBank/EMBL/DDBJ accession number for the 16S rRNA gene sequence of strain KST3-10 ${ }^{\top}$ is DQ200983. genus are related to members of the family Geodermatophilaceae and were isolated from somewhat restricted environments, such as the Baltic Sea and rock surfaces.

During the study of marine bacteria recovered from the coast of Jeju in the Republic of Korea, strain KST3-10 $10^{\mathrm{T}}$ was isolated from sand sediment from Gwakji beach; the taxonomic status of this organism was investigated by means of polyphasic characterization. Sediment samples were taken, at a depth of $1 \mathrm{~m}$, from surface water of the beach and were placed into sterilized $50 \mathrm{ml}$ Falcon tubes containing seawater. For bacterial isolation, $1 \mathrm{~g}$ sand sediment was placed into a sterile plastic tube containing $9 \mathrm{ml}$ sterile distilled water and then mixed in a tube rotator for $30 \mathrm{~min}$ at a moderate speed. Aliquots $(100 \mu \mathrm{l})$ of the serial diluent of the samples were transferred onto SC-SW agar plates supplemented with $60 \%(\mathrm{v} / \mathrm{v})$ sterilized natural seawater. The isolation medium (SC-SW agar) consisted of $1 \%$ soluble starch, $0.03 \%$ casein, $0 \cdot 2 \% \mathrm{KNO}_{3}, 0 \cdot 2 \% \mathrm{NaCl}, 0 \cdot 002 \%$ $\mathrm{CaCO}_{3}, 0.005 \% \mathrm{MgSO}_{4} .7 \mathrm{H}_{2} \mathrm{O}, 0.001 \% \mathrm{FeSO}_{4} .7 \mathrm{H}_{2} \mathrm{O}$ and $1.8 \%$ agar in $60 \%$ sterilized natural seawater and $40 \%$ distilled water $(\mathrm{pH} 7 \cdot 2)$. The isolate was maintained on ISP 2 medium (Shirling \& Gottlieb, 1966) supplemented with $60 \%$ sterilized natural seawater (YE-SW agar), and in a $20 \%$ $(\mathrm{v} / \mathrm{v})$ glycerol suspension supplemented with $60 \%(\mathrm{v} / \mathrm{v})$ sterilized natural seawater, at -20 and $-80^{\circ} \mathrm{C}$. 
Chromosomal DNA was extracted and purified by using the Wizard genomic DNA purification kit (Promega) according to the instructions of the manufacturer. The 16S rRNA gene of strain KST3-10 $10^{\mathrm{T}}$ was amplified by a PCR (Lee et al., 2000a) and was subjected to direct sequence determination using the ABI PRISM BigDye Terminator cycle sequencing kit (Applied Biosystems) and an automatic DNA sequencer (model 3730xl; Applied Biosystems). The sequence determined in this study was aligned with corresponding sequences (retrieved from GenBank) by using the CLUSTAL_X program (Thompson et al., 1997) and then manually optimized according to the secondary structure of bacterial $16 \mathrm{~S}$ rRNA. Phylogenetic analyses were performed using three treeing algorithms, namely the neighbour-joining (Saitou \& Nei, 1987), maximum-likelihood (Felsenstein, 1981) and maximum-parsimony (Fitch, 1971) methods. A phylogenetic tree was reconstructed, using the neighbour-joining method, from evolutionary distances calculated by the method described by Jukes \& Cantor (1969). The reliability of the tree topology was evaluated by bootstrap analysis (Felsenstein, 1985) of 1000 replicated datasets.

An almost-complete 16S rRNA gene sequence for strain KST3 $-10^{\mathrm{T}}$ was determined in this study (1404 nt) and was used for an initial BLAST search against GenBank: the organism was found to belong to the family Geodermatophilaceae. The sequence was aligned with the corresponding sequences of related taxa in the family Geodermatophilaceae. A total of 1387 unambiguously aligned positions present in all strains between positions 50 and 1477 (Escherichia coli numbering) were used for phylogenetic analyses. Glycomyces harbinensis was used as an outgroup for tree construction. A neighbour-joining tree (Fig. 1) showed that strain KST3$10^{\mathrm{T}}$ occupied a unique position outside the Blastococcus cluster ( $74 \%$ bootstrap support). Members of the genus Blastococcus formed a monophyletic clade with $84 \%$ bootstrap support. This relationship was supported by all treemaking methods used in this study. The organism revealed $16 \mathrm{~S}$ rRNA gene sequence similarity values of $98 \cdot 1$ and $98.2 \%$ with respect to the type strains of B. aggregatus and $B$. saxobsidens, respectively. The type strains of B. aggregatus and B. saxobsidens shared $98.2 \%$ sequence similarity with respect to each other, whereas the levels of 16S rRNA gene sequence similarity between the novel isolate and the type strains of the loosely associated relatives Modestobacter multiseptatus and Geodermatophilus obscurus were 96.9 and $96 \cdot 2 \%$, respectively.

Determination of the diaminopimelic acid isomer (Staneck \& Roberts, 1974), peptidoglycan acyl type (Uchida \& Aida, 1984), whole-cell sugars (Saddler et al., 1991), mycolic acids (Minnikin et al., 1980), polar lipids (Minnikin et al., 1977) and lipoquinones (Kroppenstedt, 1985) were performed as described previously (Lee et al., 2000b). The cellular fatty acid methyl esters were prepared and analysed according to the instructions of the Microbial Identification System (MIDI), using cells grown on TSA for 3 days at $30^{\circ} \mathrm{C}$. The diaminopimelic acid isomer of the peptidoglycan was

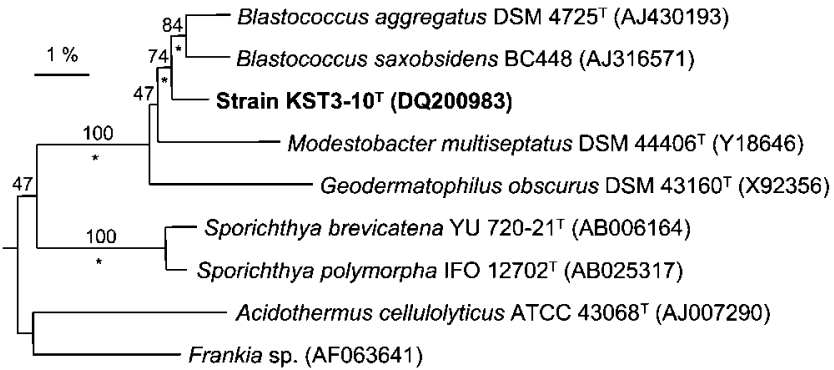

Fig. 1. Phylogenetic tree showing the relationship between strain KST3-10 ${ }^{\top}$ and representatives of the family Geodermatophilaceae based on 16S rRNA gene sequences. The tree was constructed by the neighbour-joining method from evolutionary distances calculated using the Jukes-Cantor coefficient. Micromonospora chalcea DSM 43026 ${ }^{\top}$ (GenBank accession no. X92594) was used as an outgroup (not shown). Asterisks indicate branches that are also present in the maximum-likelihood and maximum-parsimony trees. Numbers at nodes indicate bootstrap values (\%) based on a neighbour-joining analysis of 1000 replicated datasets (only values greater than $40 \%$ are shown). Bar, 1 substitution per 100 nucleotides. Note that GenBank accession no. AJ316571 lists B. saxobsidens reference strain $B C 448$ as the source, not strain $B C 444^{\top}$ as indicated by Urzi et al. (2004).

identified as the meso- form. Whole-cell hydrolysates contained arabinose and galactose as the characteristic sugars. The glycan moiety of the murein structure was acetylated. Mycolic acids were not detected. The predominant menaquinone was MK-9 $\left(\mathrm{H}_{4}\right)$. The polar lipid profile contained significant amounts of phosphatidylcholine, diphosphatidylglycerol and phosphatidylinositol. Small amounts of phosphatidylethanolamine and phosphatidylmethylethanolamine were also detected. Strain KST3-10 ${ }^{\mathrm{T}}$ could be readily differentiated from the type strains of $B$. aggregatus and $B$. saxobsidens by the absence of phosphatidylglycerol and the presence of phosphatidylcholine and phosphatidylmethylethanolamine (Urzì et al., 2004). It was shown that the presence of phosphatidylcholine, in particular, could be a chemotaxonomic marker useful for species identification. The fatty acid profile was characterized by significant amounts of iso- $\mathrm{C}_{16: 0}(32.59 \%), \mathrm{C}_{17: 1} \omega 8 \mathrm{c}$ $(11 \cdot 15 \%)$ and iso- $\mathrm{C}_{15: 0}(10 \cdot 58 \%)$ acids. Small amounts ( $>1 \%$ of total) of iso- $\mathrm{C}_{16: 1} \mathrm{H}(7 \cdot 20 \%), \mathrm{C}_{18: 0}(5 \cdot 09 \%)$, $\mathrm{C}_{16: 0}(4 \cdot 35 \%), \mathrm{C}_{17: 1} \omega 6 c(3 \cdot 89 \%), \mathrm{C}_{15: 0}(2 \cdot 68 \%), \mathrm{C}_{17: 0}$ $(2 \cdot 63 \%)$, iso- $\mathrm{C}_{14: 0}(2 \cdot 46 \%), \mathrm{C}_{15: 1} \omega 6 c(1.98 \%)$, anteiso$\mathrm{C}_{15: 0}(1 \cdot 78 \%), \mathrm{C}_{18: 1} \omega 9 c(1 \cdot 63 \%)$, anteiso- $\mathrm{C}_{17: 0}(1 \cdot 48 \%)$, iso- $\mathrm{C}_{17: 0}(1.38 \%), \mathrm{C}_{12: 0}(1.28 \%)$ and iso- $\mathrm{C}_{17: 1} \omega 9 c$ $(1.05 \%)$ were present, along with summed feature 4 $\left(\mathrm{C}_{16: 1} \omega 7 c\right.$ and/or iso- $\left.\mathrm{C}_{15: 0} 2-\mathrm{OH}, 2 \cdot 64 \%\right)$. Strain KST3$10^{\mathrm{T}}$ differed from B. saxobsidens in possessing $\mathrm{C}_{18: 0}$ and $\mathrm{C}_{12: 0}$, and in terms of the relative amounts of $\mathrm{C}_{16: 0}$, $\mathrm{C}_{17: 1} \omega 8 c$ and $\mathrm{C}_{18: 1} \omega 9 c$, and could be distinguished from $B$. aggregatus in terms of the relative amounts of iso- $\mathrm{C}_{16: 1}$, $\mathrm{C}_{17: 1} \omega 8 c, \mathrm{C}_{18: 1} \omega 9 c$ and $\mathrm{C}_{18: 0}$ acids (Urzì et al., 2004). 
Colony pigmentation was observed visually and recorded after 7 days growth at $30^{\circ} \mathrm{C}$ on YM-SW agar. Cell morphology and motility were observed using an Olympus light microscope equipped with phase-contrast optics (magnification $\times 400)$ and a transmission electron microscope. Cells were grown for 3 days at $30^{\circ} \mathrm{C}$ on YM-SW agar; cell suspensions for microscopic examination were made using sterile saline. The colonies were circular, translucent, smooth-surfaced and had entire margins. The colour of the colonies ranged from cream to apricot depending on the incubation time. The cells of strain KST3-10 $10^{\mathrm{T}}$ were coccoid and occurred in pairs or were rod-shaped, flagellated and motile (Fig. 2a). Only the rod-shaped cells showed bud formation (Fig. 2b).

The utilization of a variety of substrates as sole carbon sources was tested using GP2 microplates from the Microlog system (Biolog), which contained 95 substrates. Cells were grown for 3 days at $30^{\circ} \mathrm{C}$ on YE-SW agar and suspended in a $2 \%(w / v)$ sea-salts solution (Sigma). An aliquot $(150 \mu \mathrm{l})$ of the suspension was transferred to each well and the plates were incubated for $48 \mathrm{~h}$ at $30^{\circ} \mathrm{C}$. Reduction of the tetrazolium dye was determined by reading the absorbance of the microtitre plates at $595 \mathrm{~nm}$ using a microplate reader. Growth at various temperatures was tested $(4,10,20,30,37$, 40 and $42^{\circ} \mathrm{C}$ ). $\mathrm{NaCl}$ tolerance was studied on ISP 2 medium (yeast extract, $0.4 \%$; malt extract, $1.0 \%$; glucose, $0.4 \%$; agar, $1.8 \%$; $\mathrm{pH} 7 \cdot 2$ ) with $\mathrm{NaCl}$ added at final concentrations in the range $0-9 \%(\mathrm{w} / \mathrm{v})$. Gram staining and the hydrolysis of casein, elastin and starch were examined as described previously (MacFaddin, 1980). The decomposition of hypoxanthine, tyrosine and xanthine was tested using the method described by Gordon et al. (1974). The following tests were performed with API 20NE strips (bioMérieux): nitrate reduction, indole production, glucose fermentation, arginine dihydrolase, urease, aesculin degradation, gelatin hydrolysis and $\beta$-galactosidase. Catalase activity was determined with a $3 \%(\mathrm{v} / \mathrm{v}) \mathrm{H}_{2} \mathrm{O}_{2}$ solution. Oxidase activity was tested by assessing the oxidation of $N, N, N^{\prime}, N^{\prime}$-tetramethyl-p-phenylenediamine. Other physiological and biochemical properties were tested with API 20NE and API ZYM strips (bioMérieux) according to the manufacturer's instructions. Strain KST3 $-10^{\mathrm{T}}$ utilized Tween 80 as a sole source of carbon and energy for growth, but did not use the following substrates: $\alpha$ - and $\beta$ cyclodextrin, dextrin, glycogen, inulin, $N$-acetyl-D-glucosamine, L-arabinose, D-arabitol, arbutin, L-fucose, D-gluconic acid, $\alpha$-D-glucose, $\alpha$-D-lactose, lactulose, maltotriose, $\mathrm{D}$-melezitose, methyl $\alpha$-D-glucoside, methyl $\beta$-D-glucoside, methyl $\alpha$-D-mannoside, D-psicose, D-raffinose, salicin, stachyose, D-trehalose, D-xylose, $\alpha$ - and $\beta$-hydroxybutyric acids, $p$-hydroxyphenylacetic acid, lactamide, L-lactic acid, methylpyruvate, propionic acid, pyruvic acid, succinamic acid, $N$-acetyl-L-glutamic acid, L-alaninamide, D- and L-alanine, L-alanyl glycine, L-glutamic acid, glycyl L-glutamic acid, L-pyroglutamic acid, L-serine, glycerol, $2^{\prime}$-deoxyadenosine, inosine, thymidine, uridine, adenosine $5^{\prime}$-monophosphate, thymidine $5^{\prime}$-monophosphate, uridine
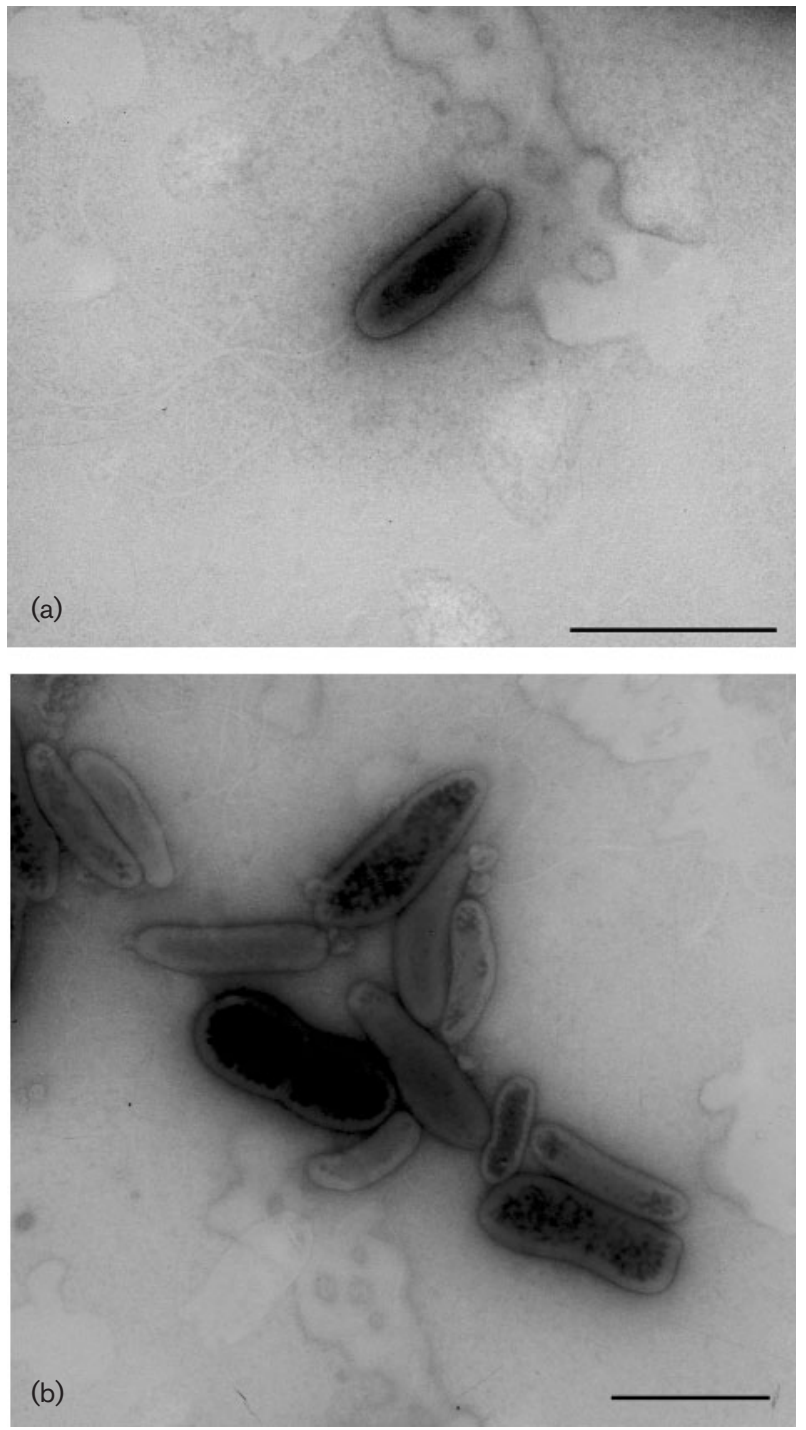

Fig. 2. Transmission electron micrographs of strain $\mathrm{KST} 3-10^{\top}$ grown on YE-SW agar for 3 days at $30^{\circ} \mathrm{C}$. (a) Rod-shaped cell with flagella. (b) Coccoid cells in pairs and rod-shaped cells showing bud formation. Bars, $1 \cdot 0 \mu \mathrm{m}$.

$5 '$-monophosphate, D-fructose 6-phosphate, $\alpha$-D-glucose1-phosphate or DL- $\alpha$-glycerol phosphate. Other physiological characteristics are given in Table 1 and in the species description.

The distinct nature of its phylogenetic position and the presence of additional phospholipids suggest that the isolate is a member of novel genus; however, the high $16 \mathrm{~S}$ rRNA gene sequence similarities (above $97 \%$ - the threshold recognized as delineating a genospecies; Stackebrandt \& Goebel, 1994) together with other phenotypic features (e.g. cell morphology, respiratory quinone and cellular fatty acid profile) indicate that the isolate should be assigned to the genus Blastococcus. Phospholipid composition has been used as a key chemotaxonomic marker in the delineation of 
Table 1. Differentiating characteristics of strain $\mathrm{KST} 3-10^{\top}$ and species of the genus Blastococcus

Taxa: 1, strain KST3-10 ${ }^{\mathrm{T}}$; 2, B. aggregatus; 3, B. saxobsidens. Data are from Urzì et al. (2004) and this study. +, Positive; -, negative; $\mathrm{W}$, weak; v, variable depending on strain; ND, not determined.

\begin{tabular}{|c|c|c|c|}
\hline Characteristic & 1 & 2 & 3 \\
\hline Cell shape & Cocci, rods & Cocci, rods, vibrios & Cocci \\
\hline Bud formation & + & + & - \\
\hline Germ tube & - & + & - \\
\hline Motility & + & + & $\mathrm{V}$ \\
\hline Colony colour & Apricot & Pink & Pink to orange \\
\hline Casein hydrolysis & + & ND & - \\
\hline \multicolumn{4}{|l|}{ API ZYM tests } \\
\hline Alkaline phosphatase & - & - & + \\
\hline Esterase (C4) & - & $+^{*}$ & $+^{*}$ \\
\hline Valine arylamidase & $\mathrm{W}$ & - & - \\
\hline Cystine arylamidase & $\mathrm{W}$ & - & - \\
\hline Naphthol-AS-BI-phosphohydrolase & - & - & $\mathrm{V}$ \\
\hline$\beta$-Glucuronidase & - & - & + \\
\hline$\beta$-Glucosidase & - & - & $\mathrm{W}$ \\
\hline \multicolumn{4}{|l|}{ API 20NE tests $\dagger$} \\
\hline Arginine dihydrolase & - & - & + \\
\hline$\beta$-Galactosidase & - & - & + \\
\hline \multicolumn{4}{|l|}{ Assimilation of: } \\
\hline D-Arabinose & - & - & + \\
\hline Gluconate & - & - & $\mathrm{W}$ \\
\hline Malate & - & - & $\mathrm{V}$ \\
\hline \multicolumn{4}{|l|}{ Biolog GP2 tests (utilization of): $\dagger \ddagger$} \\
\hline Acetic acid & + & + & - \\
\hline Adenosine & - & + & + \\
\hline$\alpha$-Ketoglutaric acid & - & + & - \\
\hline Methylsuccinate & - & + & + \\
\hline D-Ribose & - & + & + \\
\hline Tween 40 & - & + & + \\
\hline Phosphatidylcholine in polar lipids & + & - & - \\
\hline
\end{tabular}

${ }^{\star}$ Recorded as weak or positive by Urzì et al. (2004).

$\dagger$ Strain KST3 $-10^{\mathrm{T}}$ showed conflicting results for assimilation of D-mannitol, D-mannose, D-maltose and malate in the API 20NE and Biolog GP2 systems.

$\ddagger$ Biolog GP2 microplates gave positive results for strain $\mathrm{KST} 3-10^{\mathrm{T}}$ and negative results for the type strains of $B$. aggregatus and B. saxobsidens for utilization of mannan, $N$-acetyl- $\beta$-D-mannosamine, amygdalin, D-cellobiose, D-fructose, D-galactose, D-galacturonic acid, gentiobiose, myo-inositol, maltose, D-mannitol, D-mannose, D-melibiose, methyl $\alpha$-D-galactoside, methyl $\beta$-D-galactoside, 3-methyl-D-glucoside, palatinose, L-rhamnose, sedoheptulosan, D-sorbitol, sucrose, D-tagatose, turanose, xylitol, $\gamma$-hydroxybutyric acid, $\alpha$-ketovaleric acid, D-lactic acid methyl ester, L-malic acid, succinic acid, L-asparagine, putrescine, 2,3-butanediol and D-glucose 6-phosphate.

actinomycete genera or genus groups (Lechevalier et al., 1977). However, there are reports of phospholipid profiles varying according to species (Xu et al., 1999; Lee et al., 2001). The differentiating characteristics of the isolate and the type species of the genus Blastococcus are given in Table 1. On the basis of the phenotypic and genotypic data, the novel organism represents a novel species of the genus Blastococcus, for which the name Blastococcus jejuensis sp. nov. is proposed.

\section{Emended description of Blastococcus Ahrens and Moll 1970}

The description is taken from Ahrens \& Moll (1970), Urzì et al. (2004) and this study. The diagnostic diamino acid and sugars of peptidoglycan are meso-diaminopimelic acid and arabinose and galactose, respectively. The predominant menaquinone is MK- $9\left(\mathrm{H}_{4}\right)$. MK-9 occurs in variable amounts depending on the strain. The polar lipid profiles 
are characterized by the common basis comprising diphosphatidylglycerol, phosphatidylinositol and phosphatidylethanolamine. The presence of phosphatidylglycerol, phosphatidylcholine and phosphatidylmethylethanolamine is variable among the species. The major cellular fatty acids consist of saturated, unsaturated and iso-branched fatty acids. The $\mathrm{G}+\mathrm{C}$ contents of the DNA are in the range 72.3-74 mol\%. Gram-positive, oxidase-negative, catalasepositive and aerobic. Some cells may be microaerophilic. Cells are coccoid or rod-shaped and reproduce by budding and binary or multiple fission. Vibrioid or non-motile cocci occur in pairs or tend to form aggregates, whereas rodshaped cells occur singly and show motility by means of flagella. Bud formation varies according to the species. Most strains utilize a broad spectrum of organic compounds. Phylogenetically, the genus belongs to the family Geodermatophilaceae. The type species is Blastococcus aggregatus.

\section{Description of Blastococcus jejuensis sp. nov.}

Blastococcus jejuensis (je.ju.en'sis. N.L. masc. adj. jejuensis of Jeju, Republic of Korea, the site from which the type strain was isolated).

Aerobic, motile, non-spore-forming, oxidase-negative, catalase-positive, Gram-positive. Cells are cocci that occur in pairs or rods. Bud formation is observed for rod-shaped cells. Colonies are circular, smooth, transparent and apricot in colour. Starch and casein are hydrolysed, but elastin is not. Hypoxanthine, tyrosine and xanthine are not decomposed. In API 20NE tests, glucose fermentation and indole production from tryptophan are not observed. Activities of arginine dihydrolase, urease and $\beta$-galactosidase are not present. Nitrate is not reduced to nitrite. Aesculin degradation and gelatin hydrolysis are not detected. Caprate, adipate, citrate and phenylacetate are not assimilated. In API ZYM tests, results for leucine arylamidase and $\alpha$-glucosidase are positive and weakly positive, respectively, whilst results for esterase lipase (C8), lipase (C14), trypsin, $\alpha$-chymotrypsin, acid phosphatase, naphthol-AS-BI-phosphohydrolase, $\alpha$-galactosidase, $N$-acetyl- $\beta$-glucosaminidase, $\alpha$-mannosidase and $\alpha$-fucosidase are negative. The temperature range for growth is $10-37^{\circ} \mathrm{C}$, with the optimum at $30^{\circ} \mathrm{C}$. Growth occurs at $\mathrm{pH}$ values in the range $6 \cdot 1-10 \cdot 1$, with the optimum at $\mathrm{pH} 7 \cdot 1$. Growth was observed in the presence of $0-1 \%$ $\mathrm{NaCl}$ but not $2 \% \mathrm{NaCl}$. The following substrates are used as sole carbon and energy sources: mannan, $N$-acetyl- $\beta$-Dmannosamine, amygdalin, D-cellobiose, D-fructose, Dgalactose, D-galacturonic acid, gentiobiose, myo-inositol, D-melibiose, methyl $\alpha$-D-galactoside, methyl $\beta$-D-galactoside, 3-methyl-D-glucoside, palatinose, L-rhamnose, sedoheptulosan, D-sorbitol, sucrose, D-tagatose, turanose, xylitol, acetic acid, $\gamma$-hydroxybutyric acid, $\alpha$-ketovaleric acid, D-lactic acid methyl ester, succinic acid, L-asparagine, putrescine, 2,3-butanediol, adenosine and D-glucose 6-phosphate, but not Tween 40, D-ribose, $\alpha$-ketoglutaric acid or methylsuccinate. The polar lipid profile contains phosphatidylcholine, diphosphatidylglycerol, phosphatidylethanolamine, phosphatidylmethylethanolamine and phosphatidylinositol. Mycolic acids are not present. The major cellular fatty acids are iso- $\mathrm{C}_{16: 0}, \mathrm{C}_{17: 1} \omega 8 c$ and iso- $\mathrm{C}_{15: 0}$. The predominant menaquinone is MK-9 $\left(\mathrm{H}_{4}\right)$. Whole-cell hydrolysates contain meso-diaminopimelic acid as the diagnostic diamino acid and arabinose and galactose as diagnostic sugars. The DNA G $+\mathrm{C}$ content is $72 \cdot 3 \mathrm{~mol} \%$.

The type strain, KST3- $10^{\mathrm{T}}\left(=\mathrm{NRRL} \mathrm{B}-24440^{\mathrm{T}}=\mathrm{KCCM}\right.$ $42251^{\mathrm{T}}$ ), was isolated from sand sediment from Gwakji beach on Jeju Island, Republic of Korea.

\section{Acknowledgements}

This work was supported by the 21C Frontier Microbial Genomics and Application Center Program, Ministry of Science \& Technology, Republic of Korea. The author is grateful to S. H. Seo for the isolation of the novel strain and to H. L. Yang for fatty acid analysis.

\section{References}

Ahrens, R. \& Moll, G. (1970). Ein neues knospendes Bakterium aus der Ostsee. Arch Mikrobiol 70, 243-265 (in German).

Felsenstein, J. (1981). Evolutionary trees from DNA sequences: a maximum likelihood approach. J Mol Evol 17, 368-376.

Felsenstein, J. (1985). Confidence limits on phylogenies: an approach using the bootstrap. Evolution 39, 783-791.

Fitch, W. M. (1971). Towards defining the course of evolution: minimum change for a specific tree topology. Syst Zool 20, 406-416.

Gordon, R. E., Barnett, D. A., Handerhan, J. E. \& Pang, C. H.-N. (1974). Nocardia coeliaca, Nocardia autotrophica, and the nocardin strain. Int J Syst Bacteriol 24, 54-63.

Jukes, T. H. \& Cantor, C. R. (1969). Evolution of protein molecules. In Mammalian Protein Metabolism, pp. 21-132. Edited by H. N. Munro. New York: Academic Press.

Kroppenstedt, R. M. (1985). Fatty acid and menaquinone analysis of actinomycetes and related organisms. In Chemical Methods in Bacterial Systematics, pp. 173-199. Edited by M. Goodfellow \& D. E. Minnikin. London: Academic Press.

Lechevalier, M. P., De Bièvre, C. \& Lechevalier, H. A. (1977). Chemotaxonomy of aerobic actinomycetes: phospholipid composition. Biochem Syst Ecol 5, 249-260.

Lee, S. D., Kang, S.-O. \& Hah, Y. C. (2000a). Hongia gen. nov., a new genus of the order Actinomycetales. Int J Syst Evol Microbiol 50, 191-199.

Lee, S. D., Kim, E. S., Roe, J.-H., Kim, J.-H., Kang, S.-O. \& Hah, Y. C. (2000b). Saccharothrix violacea sp. nov., isolated from a gold mine cave, and Saccharothrix albidocapillata comb. nov. Int J Syst Evol Microbiol 50, 1315-1323.

Lee, S. D., Kim, E. S., Min, K.-L., Lee, W. Y., Kang, S.-O. \& Hah, Y. C. (2001). Pseudonocardia kongjuensis sp. nov., isolated from a gold mine cave. Int J Syst Evol Microbiol 51, 1505-1510.

MacFaddin, J. F. (1980). Biochemical Tests for Identification of Medical Bacteria, 2nd edn. Baltimore: Williams \& Wilkins.

Minnikin, D. E., Alshamaony, L. \& Goodfellow, M. (1977). Differentiation of Mycobacterium, Nocardia, and related taxa by thin layer chromatographic analysis of whole-cell methanolysates. J Gen Microbiol 88, 200-204.

Minnikin, D. E., Hutchinson, I. G., Caldicott, A. B. \& Goodfellow, M. (1980). Thin layer chromatography of methanolysates of mycolic acid-containing bacteria. J Chromatogr 188, 221-233. 
Saddler, G. S., Tavecchia, P., Lociuro, S., Zanol, M., Colombo, E. \& Selva, E. (1991). Analysis of madurose and other actinomycete whole cell sugars by gas chromatography. J Microbiol Methods 14, 185-191.

Saitou, N. \& Nei, M. (1987). The neighbor-joining method: a new method for reconstructing phylogenetic trees. Mol Biol Evol 4, 406-425.

Shirling, E. B. \& Gottlieb, D. (1966). Methods for characterization of Streptomyces species. Int J Syst Bacteriol 16, 313-340.

Skerman, V. B. D., McGowan, V. \& Sneath, P. H. A. (1980). Approved lists of bacterial names. Int J Syst Bacteriol 30, 225-420.

Stackebrandt, E. \& Goebel, B. M. (1994). Taxonomic note: a place for DNA-DNA reassociation and 16S rRNA sequence analysis in the present species definition in bacteriology. Int J Syst Bacteriol 44, 846-849.

Staneck, J. L. \& Roberts, G. D. (1974). Simplified approach to identification of aerobic actinomycetes by thin-layer chromatography. Appl Microbiol 28, 226-231.
Thompson, J. D., Gibson, T. J., Plewniak, F., Jeanmougin, F. \& Higgins, D. G. (1997). The CLUSTAL_X windows interface: flexible strategies for multiple sequence alignment aided by quality analysis tools. Nucleic Acids Res 25, 4876-4882.

Uchida, K. \& Aida, K. (1984). An improved method for the glycolate test for simple identification of the acyl type of bacterial cell walls. J Gen Appl Microbiol 30, 131-134.

Urzi, C., Salamone, P., Schumann, P., Rohde, M. \& Stackebrandt, E. (2004). Blastococcus saxobsidens sp. nov., and emended descriptions of the genus Blastococcus Ahrens and Moll 1970 and Blastococcus aggregatus Ahrens and Moll 1970. Int J Syst Evol Microbiol 54, 253-259.

Xu, L.-H., Jin, X., Mao, P.-H., Lu, Z.-F., Cui, X.-L. \& Jiang, C.-L. (1999). Three new species of the genus Actinobispora of the family Pseudonocardiaceae, Actinobispora alaniphila sp. nov., Actinobispora aurantiaca sp. nov. and Actinobispora xinjiangensis sp. nov. Int J Syst Bacteriol 49, 881-886. 